\title{
CHARACTERIZATION OF RED PIGMENTS EXTRACTED FROM RED BEET (BETA VULGARIS, L.) AND ITS POTENTIAL USES AS ANTIOXIDANT AND NATURAL FOOD COLORANTS
}

\author{
ATTIA, GAMILA Y., M. E. M. MOUSSA and E. R. SHEASHEA
}

Food Technology Research Institute. ARC, Giza, Egypt

( Manuscript received 29 June 2013 )

\begin{abstract}
Red pigments extracted from red beet (Beta vulgaris,L.) were identified for major constituents by using HPLC, these pigments were used as alternative natural red colorants in some processed foods, i.e. jelly and ice sherbets. Also, the effect of using red beet extract as natural antioxidant on corn oil was studied.

The results showed that red beet had $380 \mathrm{mg}$ betalain $/ 100 \mathrm{~g}$ on fresh weight. The major constituents' of red beet pigments were betalain and isobetalain by analyzing with HPLC. The best carriers for red beet pigments were dextrin followed by soluble starch, lactose and glucose, respectively. On the other hand, color and higher pigment stability of betalain pigments extracted from red beet were at $\mathrm{pH}$ ranged between 3.0 to 7.0 and temperature ranged between 40.0 to $50.0^{\circ} \mathrm{C}$. Meanwhile, the degradation of red pigments were $82.0 \%$ of the total pigments after $180 \mathrm{~min}$ at $90^{\circ} \mathrm{C}$. Antioxidant activity of red beet extracts were assessed by measuring peroxide value in corn oil during 7 days at $60^{\circ} \mathrm{C}$ corn oil contained $1000 \mathrm{ppm}$ was able to lower the peroxide value than using 200 ppm synthetic antioxidant butylated hydroxyl toluene (BHT). Analysis of variance for sensory evaluation of prepared jelly and ice sherbets indicated that, jelly samples containing $0.30 \%$ and ice sherbets containing $0.20 \%$ red beet pigments were given the highest scores of color, taste and overall acceptability similar with synthetic color carmine.
\end{abstract}

\section{Key Words:}

Betalain, natural red colorants, natural antioxidant, jelly, ice sherbets, red beet.

\section{INTRODUCTION}

Color is one of the most important attributes of foods, being considered as a quality indicator and determining frequently their acceptance. Many naturally colored foods, such as fruit products, are submitted to color losses during processing, requiring 
the use of colorants to restore their color. Natural colorants have many disadvantages when compared to synthetic ones, including higher cost in-use and lower stability. However, people have increasingly avoided synthetic colorants, preferring natural pigments, which are considered to be harmless or even healthy. Betalains are not found in plants containing anthocyanin pigments based upon their molecular structure. Henritte (2009). Betacyanins generally appear red to red violet in color they absorb in the 535$550 \mathrm{~nm}$ range - hence our choice of filter in the colorimeter) Betaxanthins generally appear yellow in color (absorb in the 475-480nm range). They cause color in both flowers, fruits and sometimes vegetative organs. They are found in the vacuole and they are water-soluble.

Betanins or betalains are natural dyes extracted from different fruits and vegetables. They are largely used as food colorants in food products like yogurts, ice cream and other products (Zhong et,al. 2005 ) and (Stintzing et,al. 2002). Recent studies have shown that betanines have antioxidant, antimicrobial and antiviral activity (Pedreno and Escribano, 2001). Beetroot (Beta vulgaris) is the main source of natural red dye, known as "beetroot red". Betanine is the main component of the red colorant extracted from Beta vulgaris. Immediately after extraction, betanine is exposed to degradation. The pigment stability is influenced by factors such as enzymes, temperature, oxygen and $\mathrm{pH}$ (Pedreno and Escribano, 2001). Betalain pigments extracted from red beet (Beta vulgaris) roots provide a natural alternative to synthetic red dyes. Betalains have been successfully used in commercial food coloring operations for a number of years (Goldman et al., 1996) and continue to be an important source of red color in the food industry. Betalains are derivatives of betalamic acid and can be classified into two groups: the red-violet betacyanins (BC) and the yellow betaxanthins (BX). These differ by conjugation of a substituted aromatic nucleus to the1, 7-diazaheptamethinium chromophore, which is present in betacyanin. Betalains are water-soluble nitrogen-containing pigments, which are synthesised from the amino acid tyrosine into two structural groups: the red-violet betacyanins and the yellow-orange betaxanthins. Beetroot pigment is used commercially as a food dye. It changes color when heated so can only be used in ice-cream, sweets and other confectionary, but it is cheap and has no known allergic side-effects. Beetroot itself, of course, is a common salad ingredient - when cooked, vinegar is added to the water to lower the $\mathrm{pH}$. Betalains have several applications in foods, such as desserts, confectioneries, dry mixes, dairy and meat products. 
The concentration of pure pigment required to obtain the desired hue is relatively small, rarely exceeding $50 \mathrm{mg} / \mathrm{kg}$, calculated as betanin (Delegado et al., 2000). According to the (Codex Alimentarius Commission. 2004), betalain - limited only by good manufacturing practice. The food colorant known as 'beetroot red' extracted from beetroots are commercialized in European Union and USA as food colorant (Castellar et al., 2003). Betanin ( $\mathrm{C} 24 \mathrm{H} 27 \mathrm{~N} 2 \mathrm{O} 13)$ makes up $75-95 \%$ of the total coloring matter found in the beet root, therefore it is used as a natural food coloring agent (Azeredo et al., 2007). This pigment, like other betacyanins, is highly susceptible to changes induced by both $\mathrm{pH}$ and temperature (Pedreno and Escribano, 2001). As a powerful antioxidant pigment, betanin may provide protection and reduce risk of cardiovascular disease and cancer (Rakin et al., 2007). Betalains are nitrogen-containing plant pigments whose colors range from red-violet betacyanins to yellow betaxanthins. They are used for coloring dairy products, meat and frozen desserts. Betalains have attracted additional interest because of their antioxidative, anti-inflammatory and anticarcinogenic properties.

The main source of commercially produced betalains is red beet root, but alternative sources are found in plants from the Amaranthaceae and Cactaceae families (Dubravko and Marijana 2011).

The aim of this research work was to obtain identify and characterize the pigments obtained from the red beet (Beta vulgaris L.), and using of these pigments as alternative natural red colorants in some processed foods (i.e.Jelly and Ice. Sherbet ). Also, to investigate the antioxidant activity of the extract through the addition to oil. Also, sensory evaluation was determined in jelly and ice sherbets after using the red beet extract as food colorant .

\section{MATERIALS AND METHODS}

\section{Materials}

Red beets (Beta vulgaris L.) were purchased from local market, Cairo, Egypt.

The solvent used for spectral and HPLC analysis were of HPLC grade and all other solvents were of ACS grade.

Refined corn oil was obtained from Arma Food Industries $10^{\text {th }}$ of Ramadan. 
Synthetic antioxidants namely butylated hydroxyl toluene (BHT) and synthetic red colorants namely carmine (alumlack of carminic acid) were purchased from Aldrich Chemical Company, USA.

\section{Analytical Methods:}

\section{Extraction and concentration of betalains pigment from red beet:}

About $200 \mathrm{~g}$ of red beet was mixed in blender with 1 liter of ethanol (acidified with $2 \%$ citric acid) for $15 \mathrm{~min}$ at room temperature and left for 24 hours. The extract were filtered and concentrated under vacuum by a rotary vacuum evaporator at $40{ }^{\circ} \mathrm{C}$. as reported by Francis (2000).

\section{Determination of total betalains:}

The concentrated red beet was diluted with distilled water and measurement was carried out at wavelength of $535 \mathrm{~nm}$ and the quantification was expressed as $\mathrm{mg}$ betalains/ 100g using the following equation as determined by Castellar et al., (2003)

Total betalains content $(\mathrm{mg} / 100 \mathrm{~g})=\mathrm{A} \times \mathrm{DF} \times \mathrm{MW} \times 1000 / € \mathrm{~L}$

Where:

A : Absorption value at535 $\mathrm{nm}$ density.

DF : Dilution volume.

L : Path length of cuvette.

MW : Molecular weight of betalain $(550 \mathrm{~g} / \mathrm{mol})$.

$\boldsymbol{\epsilon}:$ The extinction coefficient for betalain $60000 \mathrm{~L} / \mathrm{mol}$. 


\section{Selection of appropriate carrier:}

The concentrated betalains pigments were adsorbed on various supports using different ratios up to 7:1 (pigments: matrix (carrier) namely dextrin, soluble starch, anhydrous glucose and lactose and lately dried in oven at $40^{\circ} \mathrm{C}$ for 24 hours.

\section{Identification of betalains pigments by High performance Liquid Chromatography (HPLC).}

The identified of betalains pigments by HPLC Merck Pump L- 7100 according to the method reported by (Stintzing et.al., 2002) using a LC18 column $(250 \mathrm{~mm} \times 4.6 \mathrm{~mm}$, i.d). The flow rate was $1.0 \mathrm{ml} / \mathrm{min}$., the elutes were monitored by visible spectrometry at $538 \mathrm{~nm}$ and $476 \mathrm{~nm}$ for betalain. Identification was performed within a standard sample as described by the same author.

\section{Properties of betalains:}

\section{Effect of pH:}

A preliminary study was conducted to test the stability of betalain pigments in different $\mathrm{pH}$ media that ranged from 2.0 to 10.0 for $30 \mathrm{~min}$ and then percentage of color loss was calculated.

\section{Effect of temperature:}

A preliminary study was conducted to test heat tolerance of betalains pigments at different temperature ranging from 40 to $100^{\circ} \mathrm{C}$ for $30 \mathrm{~min}$ and then percentage for color loss was calculated.

\section{Thermal stability:}

Holding red colorant (betalain pigments) at $80^{\circ} \mathrm{C}$ and $90^{\circ} \mathrm{C}$ was extended for 180 min through which they were removed each 30 min and cooled immediately in an ice bath followed by measuring absorption spectra of the solution at $535 \mathrm{~nm}$. 


\section{Antioxidant activity:}

\section{Determination of antioxidant activity:}

Corn oil was used as substrate for oxidant studies .Natural antioxidant extracted from red beet $10 \mathrm{~g}$ of dried red beet extract and synthetic antioxidant butylated hydroxyl toluene (BHT) were added to oil at 200,500 , and1000 ppm on dry weight basis to test their antioxidant effectiveness, according to (Matthaus, 2002). Control sample without additives was prepared in the same condition.

Corn oil with and without antioxidant (natural or synthetic) was heated in 500 $\mathrm{ml} / \mathrm{g}$ beaker at $60^{\circ} \mathrm{C}$ (in an oven )for $3 \mathrm{~h}$ daily, the experiment was continued for 7days. The peroxide value was determined as antioxidant, for each according to the method described in (A.O.A.C .2000).

\section{Technological methods:}

\section{Preparation of jelly:}

Jelly was prepared in laboratory by adding different levels of red beet pigments i.e. $-0.10,0.20,0.30,0.40$ and $0.50 \% \mathrm{w} / \mathrm{w}$ in laboratory using the traditional procedure.

The formulation of Jelly is shown in Table (1).

Table 1. The formulation of Jelly.

\begin{tabular}{|l|c|}
\hline Ingredients & $\%$ \\
\hline Sucrose & 84.0 \\
\hline Gelatin & 15.0 \\
\hline Citric acid & 0.20 \\
\hline Flavoring agent & 0.10 \\
\hline Sodium benzoate and potassium citrate & 0.10 \\
\hline Ascorbic acid & 0.10 \\
\hline Color (red beet pigments extract) & $0.1-0.5$ \\
\hline
\end{tabular}


Jellies were wrapped by polyethylene and aluminum foil and packed in carton bags and were stored at room temperature $25 \pm 5^{\circ} \mathrm{C}$. The control of jelly was prepared with $0.10 \%$ synthetic color (carmine).

\section{3) - Ice sherbets:}

Ice sherbets was prepared in laboratory by adding different levels of red beet pigments extract ranging from 0.1 to $0.5 \%(\mathrm{w} / \mathrm{w})$ using the traditional procedure. The formulation of ice sherbets are shown in Table (2).

Table 2. The formulation of sherbets.

\begin{tabular}{|l|c|}
\hline Ingredients & $\%$ \\
\hline Sugars & 15.0 \\
\hline Water & 84.20 \\
\hline Citric acid & 0.20 \\
\hline Flavoring agent & 0.10 \\
\hline Red beet pigments (natural red color). & $0.10-0.5$ \\
\hline
\end{tabular}

These contents should be mixed very well and heated at $90^{\circ} \mathrm{C}$ for $15 \mathrm{~min}$., cooling until reaches $80^{\circ} \mathrm{C}$ and then put in polyethylene bouchs and placed in deep freezer at $-18^{\circ} \mathrm{C}$.

The control of ice sherbets was prepared with $0.10 \%$ synthetic colors (carmine)

\section{Sensory evaluation:}

Sensory evaluation was carried out by ten panelists. The panelists were asked to evaluate color, taste, odor and overall acceptability for prepared jelly and ice sherbets according to the method described by (Reitmeier and Nonnecke 1991).

\section{Statistical analysis:}

Data were statistically analyzed to facilitate comparing the least significant differences (LSD) between means of different values according to (Snedecor and Cochran 1973). 


\section{RESULTS AND DISCUSSION}

\section{Extraction and Identification of betalains from red beet:-}

Results of the extraction of betalains from red beet indicate that, the content of total betalains was $380 \mathrm{mg} / 100 \mathrm{~g}$ on fresh weights. The result obtained in general were in accordance with (Zakharova and Petrova .1997), who found that, the total betalain content of red beet were 250 to $850 \mathrm{mg} / 100 \mathrm{~g}$ on fresh weight while (Delgado et.al., 2000) found that, red pigment content in red beet could reach $500 \mathrm{mg} / 100 \mathrm{~g}$ on fresh weight.

\section{Identification of betalains extracted from red beet:-}

Separation and identification of betalain pigments from red beet was done by HPLC as seen in Table (3). Three components were identified by HPLC, the major constituent of red beet were Betalain $82.79 \%$ followed by isobetalain $11.40 \%$ and vulgaxanthin $1.34 \%$ respectively. These results are coinciding with that of (Wybraniec,2005), who mentioned that the major components of pigments in red beet are betalain and isobetalain.

Table 3. Identification of red beet pigments.

\begin{tabular}{|c|c|c|}
\hline Retention time(min) & Relative abundance area \% & Identified pigment \\
\hline 10.50 & 1.34 & Vulgaxanthin \\
\hline 23.0 & 82.79 & Betalain \\
\hline 25.7 & 11.40 & Isobetalain \\
\hline 28.9 & 4.47 & Unidentified pigments \\
\hline
\end{tabular}

*Total betalins was $380 \mathrm{mg} / 100 \mathrm{~g}$ on fresh weight. 


\section{Selection of appropriate carrier:}

The adsorption materials used as carrier for betalain pigments extracted from red beet are shown in Table (4). It could be noticed that, the presence of betalains with carriers increased gradually by increasing the level of betalain pigments in all tested carrier but disappeared or become very low by using glucose, lactose and soluble starch at $7: 1$ betalain: carrier $(\mathrm{g} / 100 \mathrm{~g})$. Results also indicated that, dextrin had the most effective adsorbent coated carrier material for betalain pigments (at high levels) which ranked as first order followed by soluble starch, lactose and glucose, where ranked in second, third and fourth orders respectively to act as_a carrier for pigments of red beet.

Table 4. Distribution pattern of betalains within selected carrier.

\begin{tabular}{|c|c|c|}
\hline Selected carrier & $\begin{array}{c}\text { Ratio of betalains to carrier } \\
\mathrm{g} / 100 \mathrm{~g}\end{array}$ & \begin{tabular}{c} 
Concentration of betalains $\mathrm{g} / 100 \mathrm{~g}$ carrier \\
\hline Soluble starch
\end{tabular} \\
\hline Lactose & $7: 1$ & 3.46 \\
\hline Dextrin & $7: 1$ & 20.63 \\
\hline Glucose & $7: 1$ & 2.25 \\
\hline
\end{tabular}

Properties of betalains extracted from red beet:

\section{Effect of pH:}

Preliminary study was conducted to test the stability of betalains pigments derived from red beet in different $\mathrm{pH}$ media. The results obtained in Table (5) show that there are relationship between color changes and $\mathrm{pH}$ variation .Most striking was the effect of on betalains content which was about 93.0 to $100.0 \%$ at pH varied from 2.0 to 7.0, while the degradation of color reached to 21.87 and $50.0 \%$ at $\mathrm{pH} 8.0$ and $\mathrm{pH} 10.0$ respectively.

Moreover, the degradation of color does not exceed $7 \%$ in the range of $\mathrm{pH}$ values 3.0 to 7.0. For instance, the highest stability remained at $\mathrm{pH} 3.0$ to $\mathrm{pH} 7.0$ since less betalain degradation were extracted from red beet These results are similar with that 
of (Castellar et al.,2003). Below pH 3.0, the absorption maximum shifts toward lower wavelengths, and above $\mathrm{pH} 7.0$ the change is toward upper ones, out of the $\mathrm{pH}$ range 3.0-7.0 the intensity of the visible spectra decreases.

Table 5. Retention\% of betalain pigments extracted from red beet as a function of $\mathrm{pH}$ values.

\begin{tabular}{|c|c|c|}
\hline pH values & $\begin{array}{c}\text { \% retained of betalain } \\
\text { pigments }\end{array}$ & \% degradation of betalain pigments \\
\hline 2 & 95.00 & 5.00 \\
\hline 3 & 95.31 & 4.69 \\
\hline 4 & 98.44 & 1.56 \\
\hline 5 & 100.00 & 00.0 \\
\hline 6 & 96.88 & 3.12 \\
\hline 7 & 93.75 & 6.25 \\
\hline 8 & 78.13 & 21.87 \\
\hline 9 & 60.94 & 39.06 \\
\hline 10 & 50.00 & 50.0 \\
\hline
\end{tabular}

\section{Effect of temperature:}

The effect of temperature on the remained and degradation rates of red beet betalains is illustrated in Table (6). Prolonged exposure of pigment at moderate temperature ranged between 40 and $50^{\circ} \mathrm{C}$, showed no degradation and similar stability were observed, whereas at above $50^{\circ} \mathrm{C}$, the degradation of betalains increased gradually by increasing temperature. For instance, the degradation in betalains pigments, caused by its exposing at high temperature. The higher degradation of betalains was observed at $100^{\circ} \mathrm{C}$ followed by 90,80 and $70^{\circ} \mathrm{C}$, respectively. While the corresponding degradation rate $19.0,36.0,46.0$ and $57.0 \%$ after exposure at $70,80,90$ and $100^{\circ} \mathrm{C}$ respectively.

The degradation rate of betalains increased gradually by increasing the temperature degree. The higher degradation rates of betalains were observed above $70^{\circ} \mathrm{C}$ and the lowest rate was below $50{ }^{\circ} \mathrm{C}$ while at $40^{\circ} \mathrm{C}$ no any degradation for betalains could 
be observed. Thus the maximum stability of pigment could be in the range of $40^{\circ} \mathrm{C}$ up to $50^{\circ} \mathrm{C}$.

Table 6. Effect of temperature on the degradation rate of betalains extracted from red beet at various temperatures for $30 \mathrm{~min}$.

\begin{tabular}{|c|c|c|}
\hline $\begin{array}{l}\text { Temperature }\left({ }^{\circ} \mathrm{C} /\right. \\
30 \mathrm{~min})\end{array}$ & $\begin{array}{c}\text { \% retained of betalains } \\
\text { pigments }\end{array}$ & $\begin{array}{c}\text { \% degradation of betalains } \\
\text { pigment }\end{array}$ \\
\hline 40 & 100 & 0.0 \\
\hline 50 & 98 & 2.0 \\
\hline 60 & 92 & 8.0 \\
\hline 70 & 81 & 19.0 \\
\hline 80 & 64 & 36.0 \\
\hline 90 & 54 & 46.0 \\
\hline 100 & 43 & 57.0 \\
\hline
\end{tabular}

\section{Thermal stability:}

The Thermal stability of betalains on duration time at various temperatures ranged between 80 and $90^{\circ} \mathrm{C}$ are evident in Table (7). Results indicate that, the increase of destruction occurred by increasing of the duration time. On the other hand, the remaining of betalains being $18.0 \%$ of the total pigments after holding for $180 \mathrm{~min}$ at $90^{\circ} \mathrm{C}$. Consequently, the exposing red beet betalains to $80-90{ }^{\circ} \mathrm{C}$ for 120 min caused a destruction reached to about $69.0 \%$ of betalains while after 180 min increased to $82 \%$ of the total betalains pigments respectively. However the temperature is considered to be the most important factor on betalain stability during food processing and storage as reported by ( Garcl et al., 1998).

Table 7. Thermal stability of betalains extracted from red beet.

\begin{tabular}{|l|c|c|c|c|c|c|c|}
\hline \multirow{2}{*}{$\begin{array}{c}\text { Betalain } \\
\text { pigments }\end{array}$} & \multicolumn{6}{|c|}{ Tolerance periods in min } \\
\cline { 2 - 8 } & Temp ${ }^{\circ} \mathrm{C}$ & 30 & 60 & 90 & 120 & 150 & 180 \\
\hline Retained & 80 & 64 & 57 & 50 & 42 & 36 & 21 \\
\hline Degradation & 80 & 36 & 43 & 50 & 58 & 64 & 79 \\
\hline Retained & 90 & 54 & 41 & 36 & 31 & 26 & 18 \\
\hline Degradation & 90 & 46 & 59 & 64 & 69 & 74 & 82 \\
\hline
\end{tabular}




\section{Antioxidant activity of red beet extract on corn oil:}

The efficiency of natural antioxidant of red beet (betalains ) extract was compared with synthetic antioxidant (BHT) measured by peroxide value (PV) and the results are reported in Table (8). from the results it could be observed that as the concentration natural antioxidant (red beet) increased there was increase in the inhibitory effect of (PV)

After 7 days of storage at $60^{\circ} \mathrm{C}, \mathrm{PV}$ values of corn oil treated with 200, 500 and 1000 ppm of red beet extract were $10.9,9.4$ and 7.80 meq $/ \mathrm{kg}^{-1}$, while the PV value of corn oil treated with $200 \mathrm{ppm}$ of BHT (synthetic antioxidant), was $8.40 \mathrm{meq} / \mathrm{kg}^{-1}$. On the other hand, the red beet extract (1000 ppm) was more effective for suppression development of PV value than BHT.

From aforementioned results, $1000 \mathrm{ppm}$ red beet extract had higher effect on controlling the development of rancidity in corn oil than that of synthetic antioxidant (BHT). In addition, the natural antioxidant extract of red beet extracts would be preferred over synthetic antioxidant to minimize the adverse health effects.

Table 8. Effect of betalains and BHT as antioxidants on peroxide value (PV) of corn oil during storage at $60^{\circ} \mathrm{C}$. for 7 days.

\begin{tabular}{|c|c|c|c|c|c|}
\hline \multirow{2}{*}{$\begin{array}{c}\text { Storage time } \\
\text { (days) }\end{array}$} & \multicolumn{5}{|c|}{ PV (meq / $\mathrm{kg}^{-1}$ ) for corn oil treated with } \\
\cline { 2 - 6 } & \multirow{2}{*}{\begin{tabular}{c} 
Control without antioxidant \\
\cline { 3 - 6 }
\end{tabular}} & & *BHT & \multicolumn{3}{c|}{ Red beet extract } \\
\cline { 2 - 6 } & 1.18 & $200 \mathrm{ppm}$ & $200 \mathrm{ppm}$ & $500 \mathrm{ppm}$ & $1000 \mathrm{ppm}$ \\
\hline 0.0 & 3.52 & 1.18 & 1.18 & 1.18 & 1.18 \\
\hline 1.0 & 5.40 & 2.73 & 3.42 & 3.28 & 2.80 \\
\hline 2.0 & 7.30 & 3.16 & 4.90 & 4.28 & 3.10 \\
\hline 3.0 & 8.25 & 3.94 & 5.30 & 4.60 & 3.80 \\
\hline 4.0 & 10.33 & 4.76 & 6.77 & 6.12 & 4.70 \\
\hline 5.0 & 14.65 & 6.21 & 8.44 & 7.11 & 6.11 \\
\hline 6.0 & 17.40 & 7.30 & 9.86 & 8.78 & 6.98 \\
\hline 7.0 & & 8.40 & 10.90 & 9.40 & 7.80 \\
\hline
\end{tabular}

*BHT : Butylated Hydroxyl Toluene 


\section{Sensory evaluation of jelly and ice sherbets:}

Sensory properties of jelly and ice sherbets prepared with adding different levels of betalain extracted from red beet as natural colorants compared with other products prepared with $0.10 \%$ synthetic red color (carmine) are given in Table (9). Analysis of variance showed mostly significant differences in color, taste, odor and overall acceptability for both jelly and ice sherbets as control or prepared by different levels of natural red color (red beet) in the range 0.1 to $0.5 \%$. The addition of natural red color from red beet with different levels significantly affected color, taste, odor and overall acceptability. However, ice sherbets prepared with levels of betalains extracted from red beet in concentration $0.10,0.40$ and $0.5 \%$ and also concentrations $0.4,0,0.50 \%$ for jelly received the lowest score in all tested quality attributes.

The jelly prepared by adding natural color from red beet at $0.30 \%$ had a highest score of investigated attributes followed by adding 0.4 and 0.2 respectively. On the other hand, the ice sherbets prepared by adding betalain extracted from red beet $0.20 \%$ had a highest score of investigated attributes followed by adding $0.30,0.10,0.40$ and $0.50 \%$ respectively.

In general, consumer perception has been that natural food colorant ingredient would be safer, healthful and considered as potential food colorants for preparing Jellies and ice sherbets. 
Table 9. Sensory evaluation of jelly and ice sherbets prepared with different levels of natural red colorants (betalain) from red beet.

\begin{tabular}{|l|c|c|c|c|c|c|c|c|}
\hline \multirow{2}{*}{ Treatments } & \multicolumn{5}{|c|}{ Jelly } & \multicolumn{3}{c|}{ Ice sherbets } \\
\cline { 2 - 9 } & Color & Taste & Odor & $\begin{array}{c}\text { Overall } \\
\text { acceptability }\end{array}$ & Color & Taste & Odor & $\begin{array}{c}\text { Overall } \\
\text { acceptability }\end{array}$ \\
\hline Control** $^{*}$ & $9.80^{\mathrm{a}}$ & $9.80^{\mathrm{a}}$ & $9.70^{\mathrm{a}}$ & $9.70^{\mathrm{a}}$ & $9.50^{\mathrm{a}}$ & $9.50^{\mathrm{a}}$ & $9.50^{\mathrm{a}}$ & $9.50^{\mathrm{a}}$ \\
\hline $\begin{array}{l}0.1 \% \text { betalain } \\
\text { pigments }\end{array}$ & $7.40^{\mathrm{c}}$ & $7.10^{\mathrm{c}}$ & $7.20^{\mathrm{c}}$ & $7.20^{\mathrm{c}}$ & $7.30^{\mathrm{c}}$ & $7.20^{\mathrm{c}}$ & $7.20^{\mathrm{c}}$ & $7.20^{\mathrm{c}}$ \\
\hline $\begin{array}{l}0.20 \% \\
\text { betalain } \\
\text { pigments }\end{array}$ & $8.40^{\mathrm{b}}$ & $8.20^{\mathrm{b}}$ & $8.30^{\mathrm{b}}$ & $8.30^{\mathrm{b}}$ & $9.50^{\mathrm{a}}$ & $9.50^{\mathrm{a}}$ & $9.50^{\mathrm{a}}$ & $9.50^{\mathrm{a}}$ \\
\hline $\begin{array}{l}0.30 \% \\
\text { betalain } \\
\text { pigments }\end{array}$ & $9.80^{\mathrm{a}}$ & $9.70^{\mathrm{a}}$ & $9.60^{\mathrm{c}}$ & $7.60^{\mathrm{c}}$ & $8.30^{\mathrm{b}}$ & $8.20^{\mathrm{b}}$ & $8.30^{\mathrm{b}}$ & $8.30^{\mathrm{b}}$ \\
\hline $\begin{array}{l}0.40 \% \\
\text { betalain } \\
\text { pigments }\end{array}$ & $8.50^{\mathrm{b}}$ & $8.30^{\mathrm{b}}$ & $8.30^{\mathrm{b}}$ & $8.30^{\mathrm{b}}$ & $7.10^{\mathrm{c}}$ & $7.20^{\mathrm{c}}$ & $7.20^{\mathrm{c}}$ & $7.10^{\mathrm{c}}$ \\
\hline $\begin{array}{l}0.5 \% \text { betalain } \\
\text { pigments }\end{array}$ & $7.10^{\mathrm{c}}$ & $7.00^{\mathrm{c}}$ & $7.00^{\mathrm{c}}$ & $7.00^{\mathrm{c}}$ & $6.00^{\mathrm{d}}$ & $6.20^{\mathrm{d}}$ & $6.10^{\mathrm{d}}$ & $6.10^{\mathrm{d}}$ \\
\hline
\end{tabular}

*values with different letters in the same column are significant different at $\mathrm{P}<.0 .05$.

** control (Prepared with $0.10 \%$ carmine as synthetic red color.

\section{REFERENCES}

1. A.O.A.C. 2000. Official Methods of Analysis of the Association of Official Analytical Chemists, 17th Ed, edited by W. Horwitz, A.O.A.C. Washington, DC.

2. Azeredo HMC, Santos AN, Souza ACR, Kenya CB, Mendes and Andrade MIR 2007. Betacyanin stability during processing and storage of a microencapsulated red beetroot extract. Am. J. Food Tech. 2, 307.

3. Castellar MR, Obo'n JM, Alacid M and Ferna'ndez- Lo'pez JA 2003. Color properties and stability of betacyanins from Opuntia fruits. J. Agr. Food Chem.51, 2772-2776.

4. Codex Alimentarius Commission 2004. ALINORM 05 / 28 / 27 -Report of the TwentySecond Session of the Codex Committee on Processed Fruits and Vegetables. Availableat:http://www.codexalimentarius/report/624/al28_27e.pdf (accessed 24 /06/2006). Rome: Food and Agriculture Organization of the United Nations.

5. Delegado,V.F, A.R. Jime'nez, and P. Lopezo 2000. Natural pigments: carotenoids, anthocyanins, and betalains - characteristics, biosynthesis, processing, and stability. Critical Rev. Food Sci. Nut. 40, 173-289. 
6. Dubravko,P. and K. Marijana, 2011. Complex biochemistry and biotechnological production of betalains. Bio technological production of betalains, Food Tech. Biotech.49, 145- 155.

7. Henriette M.C.Azerodo 2009. Betalaine:properties, sources, applications and stabilitya review. Inter]. FOOD SCIENCE AND Technology, 44,2365-2376.

8. Garcl, F.A., C.R. Reynoso, and E. Gonza 1998. Estabilidad de las betalaı'nas extraı'das del garambullo (Myrtillocactus geometrizans). Food Science and Technology International, 4, 115-120.

9. Goldman,I.L,K.A. Eagen, D.N. Breitbach, and W.H. Gabelman 1996.Simultaneous Selection is Effective in Increasing Betalain Pigment Concentration but not Total Dissolved Solids in Red Beet J. AMER. SOC. HORT. SCI. 121(1):23-26.

10. Francis, F. G. 2000. Anthocyanin and betalains composition and application.Cereal Food World, 45: 208-213.

11. Matthaus, B. 2002. Antioxidant activity of extracts obtained from residues of different oil seeds. J. Agric. Food Chem., 47:2350-2354

12. Pedreno, M.A. and J. Escribano 2001. Correlation between antiradical activity and stability of betanine from Beta vulgaris $\mathrm{L}$. roots under different $\mathrm{pH}$, temperature and light conditions. J. Sci. Food Agri. 81,627-631.

13. Rakin M, Vukasinovic M, Slavica Siler-Marinkovic and Milan Maksimovic 2007. Contribution of lactic acid fermentation to improved nutritive quality vegetable juices enriched with brewer's yeast autolysate. Food Chem. 100,599-602.

14. Reitmeier, C. A. and G.R. Nonnecke 1991. Objective and sensory evaluation of fresh fruit of day neutral strawberry cultivars. J. Hor. Sci., 26:843-845.

15. Senedecor, G. W and W. G. Cochran 1973. Statistical Methods Iowa State Univ., Press Ames, Iowa, pp. $593-610$.

16. Stintzing, F.C., A. Schieber and R. Carle 2002. Betacyanins in fruits of red-purple pitaya, Hylocereus polyrizus (Weber) Britton \& Rose", Food Chemistry, vol. 77, 2002, pp. 101-106.

17. Wybraniec, S. 2005. Formation of decarboxylated betacyanins in heated purified betacyanin fractions from red beet root (Beta vulgaris L.) monitored by LCMS / MS. Journal of Agricultural and Food Chemistry, 53, 3483-3487.

18. Zakharova,N.S. and T. A.Petrova 1997 . Investigation of betalain and betalain oxide of leaf beet. Applied Biochem. And Microbiology, 33 (5):481- 484.

19. Zhong, Y. C., M. Sun and H. Corke 2005. Characterization and application of betalain pigments from plants of Amaranthaceae, Trends in Food science \& Technology, vol. 16, 2005, pp. 370-376. 


\title{
خواص الصبغات الحمراء المستخلصة من البنجر الأحمر واستخدامها كمضاد للأكسدة وملون طبيعي للاغذيه
}

\author{
جميلة يوسف عطية محمد الأمين محمد موسى عماد الاين راغب شعيشع

$$
\text { معرة بحوث تكنولوجيا الاغنية - مركز البحوث الزراعية - الجيزة - مصر }
$$

تم استخلاص الصبغات الحمراء من البنجر والتعرف على التركيب الأساسي لهذه الصبغات بالتحليل

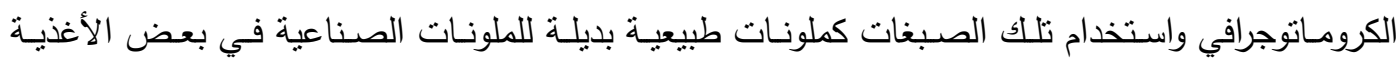

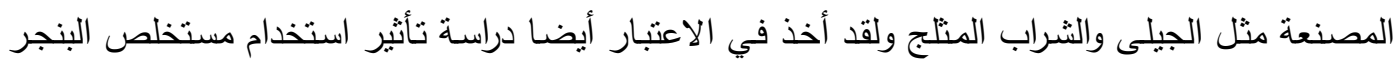
الأحمر كضاد أكسدة طبيعي في زيت الذرة.

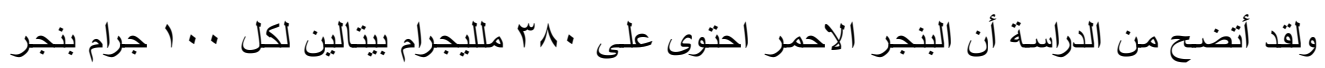

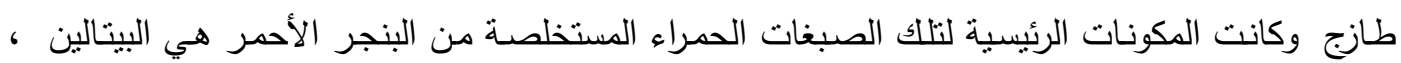

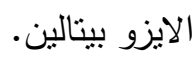

وأثنارت النتائج أن أفضل مادة لتحميل الصبغات الحمراء الدستخلصة من البنجر الاحمر كانت

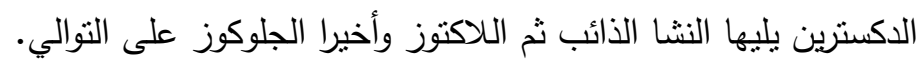

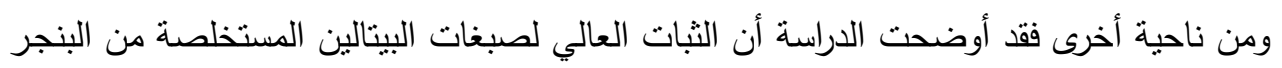

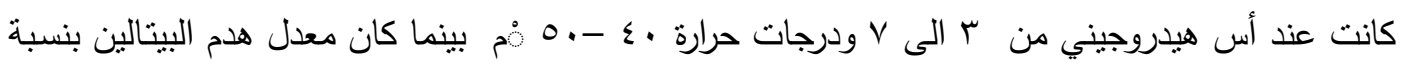

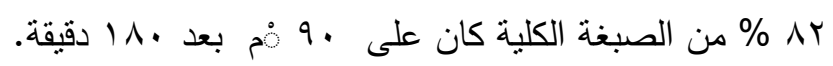

هذا وتشير النتائج إلى أنه بتقييم مستخلص البنجر الاحمر كمضاد للأكسدة عن طريق تتبع التغير

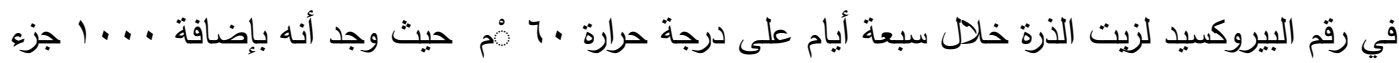

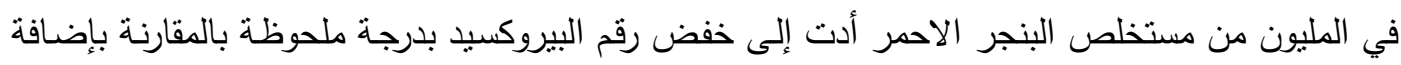

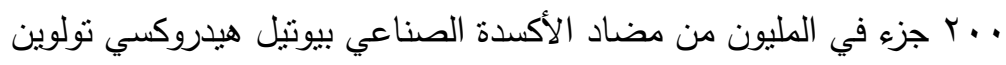

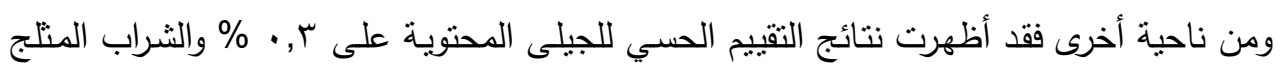

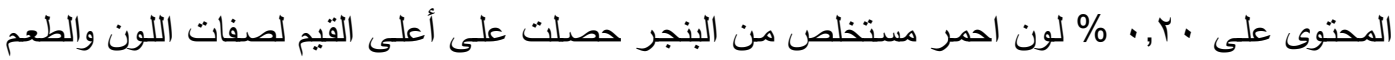
والقبول العام متماتلة مع تلك المصنعة ب باستخدام اللون الصناعي الكارمين . 